Maurer School of Law: Indiana University Digital Repository@Maurer Law

Articles by Maurer Faculty

Faculty Scholarship

1983

\title{
The Relocation of Arkansas Post to Ecores Rouges in 1779
}

Morris S. Arnold

Indiana University School of Law

Follow this and additional works at: http://www.repository.law.indiana.edu/facpub

Part of the United States History Commons

\section{Recommended Citation}

Arnold, Morris S., "The Relocation of Arkansas Post to Ecores Rouges in 1779" (1983). Articles by Maurer Faculty. 2461.

http://www.repository.law.indiana.edu/facpub/2461

This Article is brought to you for free and open access by the Faculty Scholarship at Digital Repository @ Maurer Law. It has been accepted for inclusion in Articles by Maurer Faculty by an authorized administrator of Digital Repository @ Maurer Law. For more information, please contact wattn@indiana.edu.

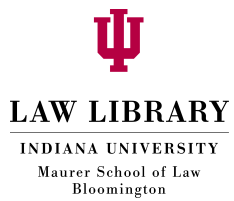




\title{
The Relocation of Arkansas Post to Ecores Rouges in 1779
}

\author{
By MORRIS S. ARNOLD* \\ University of Arkansas Law School, 400 West Markham \\ Little Rock, Arkansas 72201
}

ON September 7, 1776, Captain Balthazar de Villiers took command of the Arkansas Post of Louisiana. What he found on his arrival there did not very much please him; indeed, he soon came to regard the place as altogether intolerable. Writing to Governor Bernardo Gálvez in June 1778, De Villiers forgot his usual punctilio and indulged in a personal comment: Arkansas Post was, he said flatly, "the most disagreeable hole in the universe (le réduit le plus désagréable de l' univers). ${ }^{1}$

For De Villiers, who was well-connected and had a wife who liked to travel, his remote post was literally a slough of despond. Its location, in Desha County about ten miles above the mouth of the Arkansas ${ }^{2}$ (Figure 1), was subject to severe flooding, which De Villiers, who wrote good French and long letters, described in detail. A little less than a year after his arrival he wrote Governor Gálvez in New Orleans that "all the land [around the Post] has been covered with water for three weeks and the entire harvest has been lost - voilá for the fourth year in a row." He went on to say that "the habitants and the savages are very discouraged and desire that the post be transferred. ..." If that were done, De

*'The author is Ben J. Altheimer Distinguished Professor of Law at the University of Arkansas at Little Rock. He wishes to thank the Arkansas Endowment for the Humanities and the American Bar Foundation for supporting the research for this article, part of which was done in Seville, Spain.

${ }^{1}$ De Villiers to Gálvez, July 10, 1776, Archivo General de Indias, Papeles Procedentes de Cuba, Seville, leg. 189-2; cited hereinafter as AGI, PC, leg.; De Villiers's deprecating remark is in De Villiers to Gálvez, June 11, 1778, AGI, PC, leg. 191.

${ }^{2} I d$. to id., August 3, 1777, AGI, PC, leg. 190. 
Villiers predicted, "the number of habitants would increase." He opined that as long as the post remained where it was it was "not possible to count on any kind of harvest," and concluded by saying that "all the said habitants are desperate and on the verge of dying. . .."3

The Post of Arkansas was obviously not a place which could attract agricultural settlers, habitants in the technical sense of the word, and this was disquieting to De Villiers. He reported in 1777 that there were only seven habitant families containing in all fifty whites at the Poste des Akancas, and four of these families were headed by merchants who were in the business of equipping hunters. The habitants owned a total of eleven slaves and their village contained only eleven houses. ${ }^{4}$

De Villiers described his command as "a residence for merchants and a point of return for hunters who come here to equip themselves; [for the hunters it is] also a place to bring back the product of their hunt at the expiration of their permission, paying their debts, and

${ }^{3} I d$. to id., May 28, 1777, AGI, PC, leg. 190.

${ }^{4} \mathrm{Ibid}$. The population of eighteenth-century Arkansas had always been small. In 1765 Lieutenant Philip Pittman said of the "Post of Arkansas" that there were "eight houses without the fort occupied by as many families. . . Pittman, The Present State of the European Settlements on the Mississippi with a Geographical Description of that River (1770; reproduced with an introduction by R. Rea, Gainesville, Fla., 1973), 40. In Stanley Faye, "The Arkansas Post of Louisiana: French Domination," Louisiana Historical Quarterly, XXVI (July 1943), 681, n. 45, the author expresses the view that Pittman's description is suspect because he ascribes the wrong location to the post. In fact, Pittman was exactly correct in saying that the post was nine miles (three of his leagues) from the mouth of the Arkansas. There is therefore no reason at all to doubt that Pittman's description is accurate. Pittman, like De Villiers, remarks on the unsuitability of the location of the post for agriculture. The habitants, he noted, "had cleared the land about nine hundred yards in depth; but on account of the sandiness of the soil, and the lowness of the situation, which makes it subject to be overflowed, they do not raise their necessary provisions." Pittman, Present State of the European Settlements, 40. In 1766, a census reported forty whites and ten slaves resident at the Arkansas. Jacaueline Voorhies, Some Eighteenth-Century Louisianians, Census Records of the Colony, 1758-1796 (Lafayette, La., 1973), 157. The censuses of 1768 and 1770 indicated that the white population was around eighty, but those counts included some hunters who probably ought not be be considered true habitants. Recensement des habitants, femmes, enfants, et esclaves du Poste des Arkansas, AGI, PC, leg. 107; Estada presente de todo los inhabitantes del puesto de los Arkancas ... , AGI, PC, leg. 107. In 1771 there were only sixty-two whites and eleven slaves at the post. Lawrence Kinnaird, ed., Spain in the Mississippi Valley, 1765I794 (3 parts, Washington, D. C., 1949), I, 196. 
equipping themselves again or taking their catch to town [i.e., New Orleans]." 5 Trade with the Indians, De Villiers said, was of "very little importance and not worth the trouble of establishing a trader [at the Quapaw villages]." Besides, he noted, "when these savages need anything they bring the few pelts they have either to the Post or to the English [at Concordia, on the left bank of the Mississippi across from the mouth of the Arkansas], and the major part of the trade is for liquor." 6

De Villiers was not at all reticent about expressing his view of the quality of his European population. There were a large number of French hunters up the Arkansas, St. Francis, and White rivers, most of whom were not included in the censuses, and many of whom sometimes refused even to admit allegiance to any organized government. De Villiers often expressed his wish to the governor that the Arkansas could become what he called a "respectable post." "The families of the hunters are," he once remarked, "for the most part lazy people of bad breeding." What was needed was "farmers without the embarrassment of the hunters' families." 'In other words, De Villiers dreamed of creating a stable agricultural community in Arkansas, and he knew that that was impossible at a location so close to the river's mouth.

The post had not always been situated at a place vulnerable to flooding, and De Villiers knew it. In an extremely interesting report of his situation in $\mathbf{1 7 7 7}$ he outlined the history of Arkansas Post for the governor's benefit and urged its relocation to higher ground. It had been moved downstream in 1756 to the site from which he wrote; its previous position had been at a place called Ecores Rouges (Red Bluffs), fifteen leagues (thirty-six miles) from the mouth of the Arkansas. This is the place where the Arkansas Post National Memorial is presently located. The post had been moved there in 1749 but since its situation was inconvenient for the Mississippi convoys it had been relocated to Desha County. But De Villiers claimed that when it was moved "the commerce from Illinois . . . was considerable, the king sending several boats every

\footnotetext{
${ }^{5}$ The merchants were Jean Francois Menard, Pierre Perthuis, Jean Baptiste Duchassin, and Andre Lopes. Lopes had a post about seventy miles upriver from the settlement.

${ }^{6}$ De Villiers to Gálvez, August 3, 1777, AGI, PC, leg. 190.

${ }^{7}$ Id. to id., March 2, 1779, AGI, PC, leg. 192.
} 
year"; by 1777, he asserted, Mississippi commerce consisted of only "four or five boats a year owned by private persons." Besides, when the settlement was relocated it was flooded "only every eight or nine years," but by 1777 it was "regularly underwater every year." Arguing for permission to move his settlement back to Ecores Rouges, he claimed that the few boats that required the services of an entrepôt could "just as well, and a good deal more securely, be resupplied eleven leagues higher up where cattle and other produce could be available without any obstacle." Moreover, the good captain argued, to such a place one could attract "habitants of a respectable sort." Ecores Rouges was also a superior strategic location to the downriver site, he said, because it was above the forks and thus afforded a better possibility of preventing the intrusions of the English. ${ }^{8}$

The English were doing considerable damage in the Arkansas region, depleting the game and causing the French hunters to have to range as far as 500 miles up the Arkansas. De Villiers said that the damage done by the English would soon be "irreparable if one does not find a way to dislodge them." ${ }^{9} \mathrm{He}$ claimed that there were at least eighty English hunters operating in his bailiwick, and noted that with the post below the forks it was "impossible to keep them from coming in." ${ }^{10}$ Another possible site for relocating the post, also strategically located above the forks and thus useful for immigration control, was at the place where the post had been in 1749 when it was attacked and burned by the Chickasaws. The habitants had been taken by surprise, and six male settlers had been killed, and eight women and children captured, while trying desperately to reach the safety of the fort. ${ }^{11}$ According to De Villiers, this settlement had been located five leagues from his position, at three leagues upriver from the forks and five leagues downriver from Ecores Rouges. It was at "the base of a small prairie which gave the habitants the capacity to supply themselves and grow tobacco. ..." It had become, by the time De Villiers took command, "separated from

${ }^{8} I d$. to $i d$. , August 3, 1777, AGI, PC, leg. 190.

${ }^{9}$ Ibid.

${ }^{10} I d$. to $i d$., August 4, 1777, AGI, PC, leg. 190.

${ }^{11}$ Faye, "The Arkansas Post of Louisiana: French Domination," 684. This is the position which Law's colony occupied as well. 
the river by the changing of the shoreline." This is obviously the edge of what is today called Little Prairie on the banks of Lake Dumond in Arkansas County. The post had been removed to Ecores Rouges a short time after its destruction by the Chickasaws. ${ }^{12}$

De Villiers very seriously considered moving back to the Lake Dumond location when the Quapaws asked him to do so in 1778. This position, which De Villiers calls the "first establishment," he at first thought quite suitable; and he expressed the view that the post had been moved upriver in 1749 to Ecores Rouges "without very good reason." The site of the "first establishment" had the added advantage of being close to the forks and so no great inconvenience would accrue to Mississippi convoys. Moreover, the captain said, "at a few arpents from this settlement [is] located a vast terrain or prairie about five leagues in circumference suitable for all sorts of agriculture"; and there was a bayou there "which in high water connects with the White River." 13

One of the difficulties which flooding caused was that it hindered defense of the post. The Quapaws, whose villages were all within three leagues by land of the post ${ }^{14}$ and who numbered only $509,{ }^{15}$ were dispersed by the floods and would be unable to come to the aid of the tiny European settlement in the event of attack. ${ }^{16}$ The Quapaws were essential to the security of the post, and they were therefore consulted and paid careful attention to whenever any decision of moment was being made there. As noted above, they wanted to return to the 1749 site and thus De Villiers gave the suggestion a lot of thought. However, a visit there revealed that it was in fact unsuitable. De Villiers wrote to the governor that, though he had previously considered removing to "the place of the old settlement [ancien éstablissement], . . a after having visited it I have realized that the river had made a cutoff . . . [and] it would be impossible in ordinary waters to land there." He noted, moreover, that "the banks would be beyond cannon range" and thus boats and ships could pass without challenge. ${ }^{17}$

12 De Villiers to Gálvez, June 11, 1778, AGI, PC, leg. 191.

${ }^{13}$ Id. to id., September 27, 1778, AGI, PC, leg. 191.

${ }^{14}$ Dénombrement du Poste des Akancas . . . , August 3, 1777, AGI, PC, leg. 190.

${ }^{15}$ lbid.

${ }^{16}$ De Villiers to Gálvez, September 27, 1778, AGI, PC, leg. 191.

${ }^{17}$ Id. to id., February 20, 1779, AGI, PC, leg. 192. 
While the commandant was making up his mind about a new site, events connected with the American Revolution would soon make removal more urgent. The Spanish had at first affected to maintain a neutrality in the conflict between Britain and her American colonies and post commandants had been instructed to show a perfect impartiality between the subjects of his Britannic Majesty and the confédérés Américains." ${ }^{18}$ On February 2, 1778, thirteen Anglo-American refugee families petitioned the commandant to be allowed to settle at Arkansas Post. They had intended to settle at Concordia, or British Ozark (aux arcs); but on arrival there they had found the place deserted. Being attached to the American cause, they were afraid to stay at Concordia since that would expose them to the risk of being "troubled by the Indians faithful to Britain." The captain granted them asylum until the governor decided what to do. ${ }^{19}$ Many of them took up residence, and on March 2, 1778, De Villiers sent a census of the Anglo-American "families and hunters

${ }^{18}$ Id. to $i d$., September 2, 1778, AGI, PC, leg. 191.

${ }^{19} \mathrm{Id}$. to id., February 2, 1778, AGI, PC, leg. 191.

Notes to Figure 1. (opposite page) $\mathbb{3}$

${ }^{1}$ Tonti's trading post and entrepôt, established in 1686 and abandoned by 1699, was very probably here at the foot of Little Prairie. See James A. Ford, "Menard Site: The Quapaw Village of Osotouy on the Arkansas River," in Anthropological Papers of the American Museum of Natural History, XLVIII (New York, 1961), 139-40. Law's Colony, founded in 1721, was here as well, and the post remained here until attacked by the Chickasaws in 1749.

${ }^{2}$ The post was moved in 1749 to Ecores Rouges. See Denombrement du Poste des Akancas et de la Nation Sauvage de ce nom . . . August 3, 1777, AGI, PC, leg. 190; Etat Actuel du Poste des Akanzas, June 11, 1778, AGI, PC, leg. 191. In the latter document De Villiers wrongly gives the date of 1754 for the 1749 attack on the post by the Chickasaws.

${ }^{3}$ The post was moved here in 1756 because the Ecores Rouges site was too inconvenient for the Mississippi convoys. See Morris S. Arnold, "The Removal of Arkansas Post in 1779," Grand Prairie Historical Society Bulletin, XXV (October 1982), 31. It remained here until relocated again to Ecores Rouges in 1779. De Villiers called the fort here Fort St. Louis. See Dénombrement du Poste des Akancas et de la Nation Sauvage de ce nom ... . August 3, 1777, AGI, PC, leg. 190. This is the Arkansas Post of which Burney B. McClurkan found remains in 1971. See McClurkan, "Fort Desha, The Location of Arkansas Post ca. 1735-1750," Conference on Historic Site Archeology Papers, VI (Charleston, W. Va., 1971), 32. 


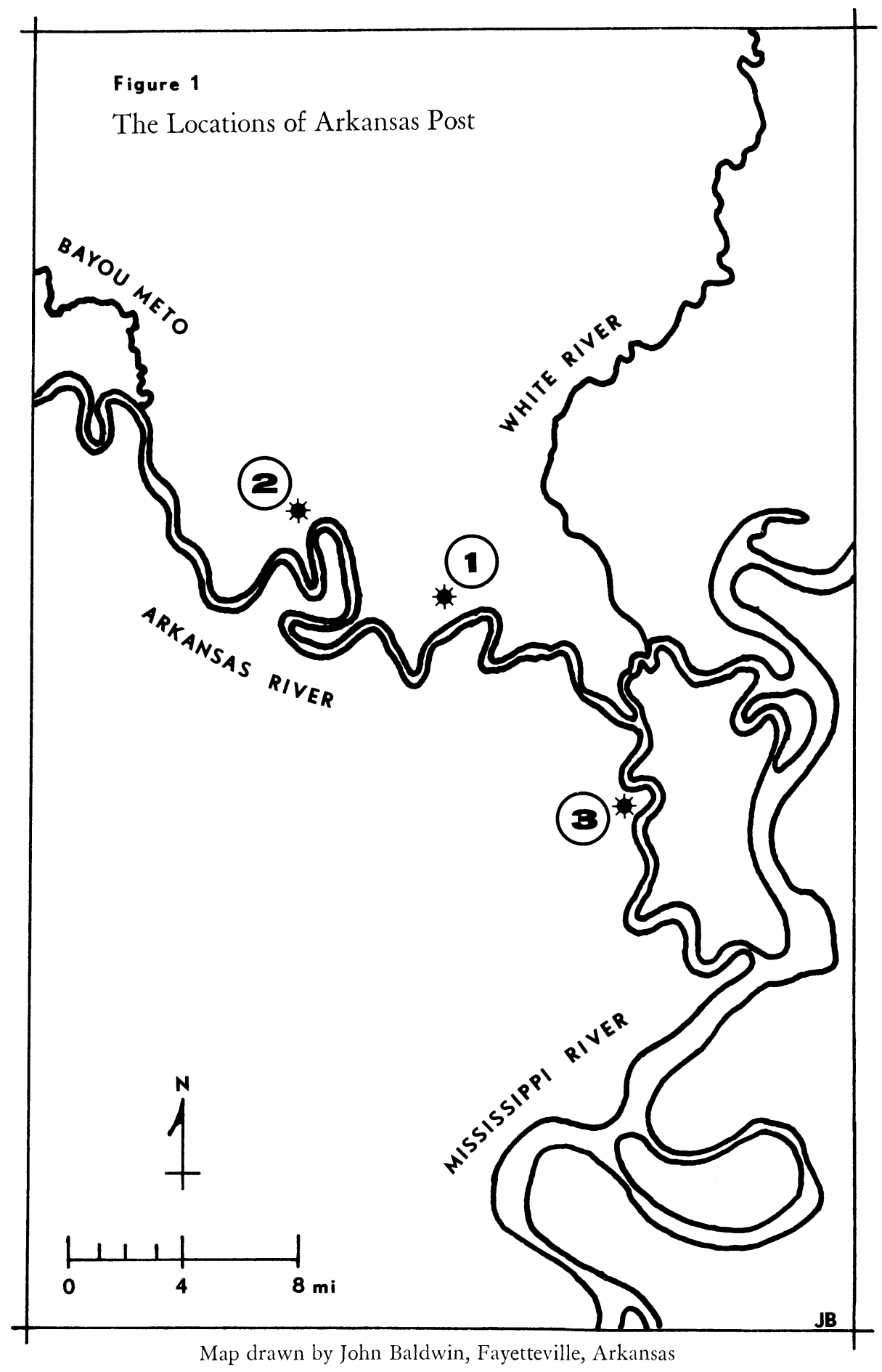




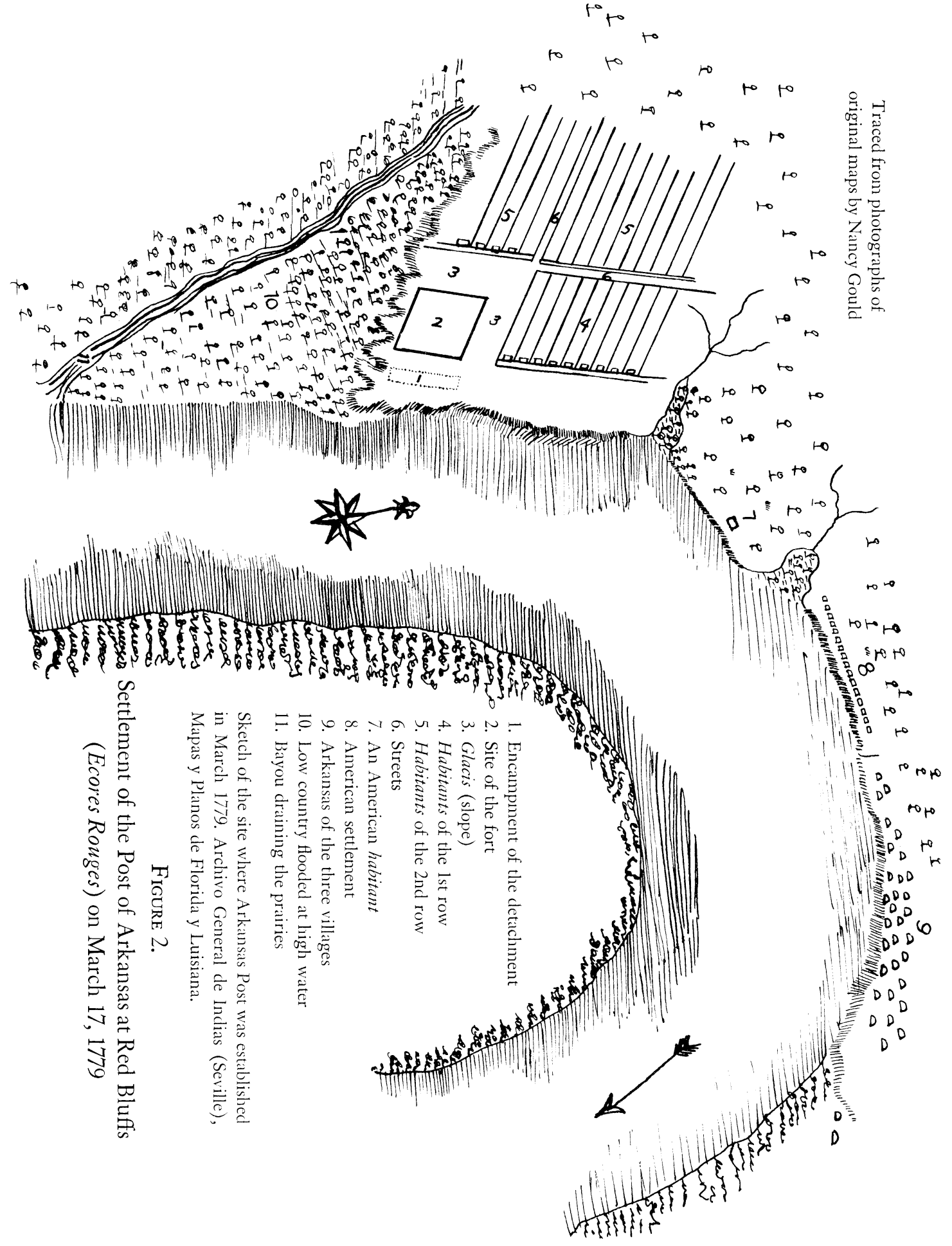


who have taken refuge in this Post of the Arkansas" since February 20, 1778. The census lists eight families totalling fifty persons and eleven bachelors who were hunters. ${ }^{20}$ On August 31, 1778, two more barge-loads of Anglo-Americans arrived at the post seeking asylum. De Villiers informed the governor that he had given them refuge and that if other "foreign families fleeing the horrors of war arrive, I propose, awaiting your orders, to receive them." ${ }^{21}$ They were given hunting rights "to support their families," but they soon found themselves "chased, hunted, and pillaged by the Pawnees and others." 22

All these new arrivals probably tripled the white population of Arkansas Post and must have placed a great strain on a community already much in distress. There was no way to support refugees at the post and it must have been obvious to everyone that something had to be done soon. The spring floods of 1779 simply made it impossible to remain any longer at the old site. ${ }^{23}$ De Villiers wrote that "this post finds itself in such desperate circumstances that I am planning to move it . . . to a more convenient place." He said that it was "hardly possible to hold on any longer in this post. . . . The continual floods have put us under water and I do not see a possibility of getting out of it before June." ${ }^{24}$ By February 17 there were two feet of water in the fort ${ }^{25}$ and three days later the commandant wrote that "having visited all the environs of this post I have not found a more appropriate place to make a settlement than Ecores Rouges. . . ." The lands there, he said, are "beautiful and suitable for all kinds of agriculture." ${ }^{26}$ In a previous letter he had described the place as on the edge of "a vast plain" where "habitants, families of hunters, and others . . . would voluntarily establish themselves," it being "a land which could produce excellent tobacco . . . and all the charms of life [toutes les douceurs de la vie]." ${ }^{27}$

${ }^{20}$ Id. to id., March 2, 1778, AGI, PC, leg. 191.

${ }^{21}$ Id. to id., September 2, 1778, AGI, PC, leg. 191.

22 Id. to id., December 3, 1778, AGI, PC, leg. 192.

${ }^{23}$ Id. to id., February 2, 1779, AGI, PC, leg. 192.

${ }^{24}$ ld. to id., February 6, 1779, AGI, PC, leg. 192.

${ }^{25}$ Id. to id., February 17, 1779, AGI, PC, leg. 192.

${ }^{26}$ Id. to id., February 20, 1779, AGI, PC, leg. 192.

${ }^{27} I d$. to $i d$., June 11, 1778, AGI, PC, leg. 191. De Villiers also considered moving his establishment down to Point Chicot on the Mississippi River. "They say," the captain 
By March 2, the floods had completely undone the tiny Arkansas community: There was water in even the most elevated house, most of the animals were drowned, the fort was open in several places, and the well had caved in. De Villiers at that point broke the news to his habitants that they should prepare themselves to follow him to Ecores Rouges. They were not inclined to do so. "Not being assured of being protected by a fort," they were at first determined to abandon the Arkansas altogether for lower Louisiana rather than "expose themselves to the incursions of the savage Chickasaws who menace us." The families of some hunters previously resident on the St. Francis and those of the Anglo-American refugees, however, were no longer able to hold on at the post, and were more willing to go upriver; and De Villiers planned to lead them within two days' time to Ecores Rouges where they would build some cabins. The Indians enthusiastically approved De Villiers's plan. $^{28}$

On March 16 the captain moved himself and part of his detachment to the new situation with, he claimed, the unanimous consent of his habitants. He does not explain what accounted for their change of heart. A week later he wrote an interesting description of his new location. "The Ecores Rouges," De Villiers said, "situated on the left bank of this river, extend about half a league and form three hills each separated by some low country." On the first hill in ascending the river some of the Quapaws had already assembled and De Villiers hoped that soon he could persuade the rest of them to follow suit. On the second hill the captain had placed the Anglo-American refugee families; and on the third he had situated his French habitants and projected a fort. ${ }^{29}$ Three weeks later the commandant informed the governor that "the new post now contains all the habitants of the old one. Their houses are built or in

\footnotetext{
wrote of Point Chicot, "that it is raised above the highest waters and is a place where it is possible to establish a good number of families. [But] I do not believe that it is a convenient place. . . ." De Villiers explained that its position was eighteen leagues below the mouth of the Arkansas, and thus too far out of the way as far as controlling English intrusions was concerned. There was, De Villiers asserted, simply no getting around the fact that "it appeared necessary that there be on the river itself a respectable post. . .."

${ }^{28}$ Id. to id., March 2, 1779, AGI, PC, leg. 192.

${ }^{29}$ Id. to id., March 22, 1779, AGI, PC, leg. 192.
} 
preparation and the livestock that was saved [has also arrived]." ${ }^{30}$ With this letter De Villiers sent a map of his new establishment, drawn to scale and giving an excellent picture of his circumstances (Figure 2). He had put the habitants on two streets. On the river front (the first row of houses) he had placed the merchants and others who hardly ever bother to make a crop"; and on the back row he had placed "the farmers, to whom I shall give a depth which you judge to be appropriate and which is proportionate to the small frontage which they have." $\mathrm{He}$ explained that the habitants' lots were only twenty toises (about forty-two yards) wide "in order to put them as close to the fort as possible." This was a far cry from the usual width of a holding in a Louisiana common field and was made necessary by the danger of Indian attack. The projected fort was to be built only about seventy yards from the cliff because the river had formed a batture (gravel beach) that "widens constantly and thus protects the bank from caving in." Though he was obviously quite pleased with his prospects, De Villiers again cautioned the governor that "to give any stability to this new settlement it is necessary to have farmers." ${ }^{11}$ Only a little more than two weeks later the commandant wrote proudly that "this new post finds itself completely established," 32 and in December he told the governor that the "post having taken a definite shape [forme déterminé] I have taken it on myself, monsieur, to give it the name of Charles the Third." ${ }^{33}$ De Villiers frequently thereafter dated his letters Post de Charles Trois de Arkansas.

The captain remembered to be concerned about the settlers' title to their land. "The habitants have built on the assurance which I have given them that you will not change anything in the dispositions which I have made in the arrangement of their lands," he wrote the governor, and he asked approval of what he had done. "Please authorize me," he requested, "to guarantee them their property." ${ }^{34}$ The governor replied that De Villiers should send the habitants' papers to him so that he could execute grants in proper form "in order to avoid their titles being put in

\footnotetext{
${ }^{30}$ Id. to id., April 10, 1779, AGI, PC, leg. 192.

31 lbid.

32 De Villiers to Gálvez, April 28, 1779, AGI, leg. 192.

${ }^{33}$ Id. to id., December 7, 1779, AGI, PC, leg. 192.

${ }^{34}$ Id. to id., April 28, 1779, AGI, PC, leg. 192.
} 
question in the future." ${ }^{35}$ This was in accord with the regulations, promulgated in 1770 by General Alexandro O'Reilly, which required all grants to be made by the governor. ${ }^{36}$ Those same regulations required the governor to send a surveyor to fix the bounds of all grants in the presence of the commandant of the district and two adjoining landowners. ${ }^{37}$ There is no indication that De Villiers ever provided the governor with the papers requested, and there is no evidence that any Spanish surveyor was at work in Arkansas until very late in the century.

In the same letter in which he requested the governor's help on land titles, the captain identified another pressing need of his fledgling establishment, and in doing so divulged important information about the nature of his population. "The few habitants there are at this place, nearly all hunters and always outside, desire for their safety and that of their families to have a fort and a detachment capable of protecting them." He stressed that without these precautions there could never be "a respectable settlement" on the Arkansas. Doors, windows, and frames from the old fort could be used, leaving as the greatest expense a "palisaded fortification sufficient to repel the savages." Perhaps the habitants should be compelled to contribute, he opined, but since the fort was to be only about seventy-five or eighty yards square it should not prove to be too expensive.

According to De Villiers's map, the new post had thirty houses and perhaps ten acres of land devoted to agriculture, and was perched on a highland on a horseshoe bend of the Arkansas River. Seventeen of these houses, however, belonged to the American refugees and were only temporary. De Villiers calls them cabans in his letters. Of the other thirteen houses (called maisons by De Villiers, an indication of greater permanence), only four were on the back row which the commandant had reserved for farmers. De Villiers gave each of the American refugees only twenty feet of land on the river, and his maps shows at the Etablissement Americain no fields behind their cabins.

${ }^{35}$ Gálvez to De Villiers, no date, 1779, AGI, PC, leg. 192.

${ }^{36}$ Translations of these regulations are available several places. I have used the version that appears in Joseph White, comp., A New Collection of Laws, Charters, and Local Ordinances. . . . (2 parts, Philadelphia, 1839), II, 231-33. The relevant partion is $§ 39$.

${ }^{37}$ Ibid. 
In the spring of 1780 nine American agricultural families arrived from Illinois, as did a number of others from South Carolina. ${ }^{38}$ De Villiers must have felt himself on the verge of success in his effort to make a respectable village of Arkansas Post. In May he wrote excitedly that "an American family composed of nine persons has arrived to stay. They came from Illinois and ought to be followed by several others, all farmers. This is going to give this post a stability which it has never had. I am doing my best to encourage them." ${ }^{39}$ That summer, the commandant formed the first militia company in Arkansas, "the habitants of the post having reached a sufficient number"; there were two units, one for the French and another for the Americans. ${ }^{40}$ In the fall, sixteen more American families arrived and the captain said that he was "going to give them settlements." ${ }^{\text {"11 }}$ The Arkansas Post of Louisiana was experiencing an enormous population increase.

However, in 1782 the commandant reported a total of only fifteen habitant families at the Arkansas; and five of these abandoned the river later that year. ${ }^{42}$ This loss of population is almost certainly attributable to the cataclysmic events which occurred at the post in the early 1780s. Only a very few months after the 1779 map was drawn, Spain sided with the American colonists and declared war on Great Britain. ${ }^{43}$ Arkansas Post was the most vulnerable of all the Spanish forts in the Mississippi valley because of its isolation and the smallness of its garrison. Until it was reinforced by twelve soldiers in 1781, the garrison at full strength had boasted only a captain and twenty soldiers. The possibility of a British attack on the post was therefore very much on the minds of its military and civilian residents. In this tense atmosphere, two German

${ }^{38}$ Marjorie O. Thomas, “The Arkansas Post of Louisiana, 1682-1783” (unpublished M. A. Thesis, University of California, Berkeley, 1948), 75. In April 1780 the commandant reported that "twenty American families coming from South Carolina have arrived at the mouth of this river; seven asked me for settlements in this post which $\mathrm{I}$ have given them awaiting your orders." De Villiers to Gálvez, April 27, 1780, AGI, PC, leg. 192.

${ }^{39}$ De Villiers to Gálvez, May 15, 1780, AGI, PC, leg. 192.

${ }^{40} \mathrm{ld}$. to $i d$., July 18, 1780, AGI, PC, leg. 192.

${ }^{41}$ Id. to id., October 16, 1780, AGI, PC, leg. 192.

42 Faye, "The Arkansas Post of Louisiana: French Domination," 639.

43 What follows is based on Gilbert C. Din, "Arkansas Post in the American Revolution," Arkansas Historical Quarterly, XL (Spring 1981), 4-30. 
soldiers (members of the Spanish detachment) and several American settlers at the post were accused early in 1782 of plotting to betray it. They had planned to open the gates of the fort to British sympathizers who would then butcher the garrison. De Villiers took depositions from various people, including those accused, and sent the record and the defendants to New Orleans where a special tribunal sentenced two of the Americans and the two German soldiers to death. ${ }^{44}$

Suspected of treason, and many of them probably still segregated in hovels, the Americans remaining behind must have felt at the very least unwelcome and would have been justified in feeling apprehensive as to their safety. When De Villiers called up the militia a few months later, only five "honest" farmers among the Americans were included in the call; the rest, he said, remained suspect following the conspiracy. ${ }^{45}$ It is no wonder that so many American families had emigrated by the end of 1782.

On April 17, 1783, at 2:30 a.m., a pro-British force of fewer than seventy men, mostly Chickasaws, led by the squawman James Colbert, struck the Arkansas Post. They had managed to reach the settlement without alerting the patrol. They killed two soldiers, wounded another, and captured an officer, six soldiers, and five habitant families. After a very considerable battle during which the soldiers in the fort fired perhaps 300 cannon rounds, a daring sally from the fort by a force of ten soldiers and four Quapaws so unnerved Colbert's band that it beat an immediate retreat. ${ }^{46}$ Only four years after having reestablished itself primarily for the purpose of attracting settlers, therefore, the hapless Arkansas settlement was in a shambles. Its little community rent by treason, executions, and warfare, it had once again established itself as a place to avoid.

De Villiers did not live to see this dénouement. In the spring of 1782 he had taken gravely ill and Lieutenant Louis de Villars had been obliged to take command. That June, De Villiers had travelled to New Orleans where he underwent on operation for a tumor on his liver. $\mathrm{He}$

${ }^{44}$ Ibid., 13, n. 18; Faye, "The Arkansas Post of Louisiana: French Domination," 671.

${ }^{45}$ Din, "Arkansas Post in the American Revolution," 17.

${ }^{46}$ Ibid., 23-25. 
died on June $19,{ }^{47}$ with many debts and an insolvent estate, his aim of a "respectable post" on the Arkansas unrealized. Thanks to his efforts, however, the prospects for a lasting settlement in Arkansas were much improved, and there is evidence that some progress, though it was more than slow, was thereafter made in the Arkansas country. The American refugees abandoned the place altogether, but in 1791 the census revealed a European population of 107, living in twenty-seven habitant households at the Poste des Akanzas; twenty-one of the households were French, one Spanish, and five German-American. There was a carpenter, a craftsman (menuisier), one laborer, two seamstresses (both of mixed French and Indian blood), five merchants and twenty-six who claimed to be farmers (cultivateurs). But the sixteen farmer households produced that year only 126 barrels of wheat and 1,815 barrels of corn. This gives rise to the suspicion that perhaps some of these so-called cultivateurs were in fact hunters for the most part. ${ }^{48}$

In 1793, Captain Pedro Rousseau, commander of a Spanish war galiot called La Flecha, visited the post and reported there a village of about thirty houses "with galleries around, covered with shingles, which form two streets." Below the fort "were a dozen quite pretty houses of four by four arpents, where there are very beautiful fields of wheat." ${ }^{49}$ The fort itself, however, did not impress a 1796 visitor, Victor Collot, who gives a somewhat different perspective. "Two ill-constructed huts, situated on the left," he sneered, "surrounded with great palisades, without ditch or parapet and containing four six-pounders, bear the name of fort." The village Collot described as being "a little behind this fort," and, he said, "it may contain from forty to fifty whites." He claimed that since the habitants had "no means of defense against the Indians, who are continually pillaging their cattle and robbing them of their industry, they are in general poor and miserable." He did, however, single out the German Michael Wolf for praise: Wolf, he said, produced wheat that

${ }^{47}$ Ibid., 17.

48 Resencement du Poste des Arkansas de l'Anné I791, AGI, PC, leg. 2365. Dorothy Jones Core has very kindly spent many hours with me analyzing eighteenth-century Arkansas censuses and identifying the nationality of those enumerated in them.

49 Rousseau's journal is translated in Abraham P. Nasatir, ed., Spanish War Vessels on the Mississippi, 1792-1796 (New Haven, 1968). The portion quoted appears on pp. 165-66. 
was "certainly equal to that of the best departments of France."

Almost simultaneously with Collot's visit a signal event in the history of the post occurred. In August 1796 Father Pierre Janin established himself as pastor of the parish of los arcos which had been created a few months earlier. This was the first canonical parish ever created in the Arkansas country, and Janin was the first resident priest there since Father Carette, a Jesuit, had resigned his post in despair in $1758 . .^{51}$ The Arkansas Post was struggling for a kind of maturity, but maturity did not prove easy to achieve. In 1799 Father Janin left to become pastor at St. Louis. No replacement was sent; indeed, no Roman Catholic parish would be established again in Arkansas until just prior to statehood.

The 1798 census enumerated 344 white persons and 56 slaves at Arkansas Post. The total corn harvest, however, had actually decreased from its 1791 level. Some of this population increase, moreover, was apparent only since people who had been resident in the Arkansas earlier were counted in this census for the first time. ${ }^{52}$ This may be because the commandants began to take a more expansive attitude toward their census-taking, including geographical portions of Arkansas or classes of people (coureurs de bois) not included before, or because hunters had gradually begun to make the post their headquarters. In any case, it appears that the hunters had continued to form the bulk of the Arkansas population, as an extremely interesting account of the post written in 1802 by Perrin du Lac reveals. He described the Village des Arkansas as follows:

The habitants, almost all originally French emigrants from Canada, are hunters by profession, and grow only corn for the nourishment of their horses and of a small number of cattle used in plowing. More than half the year one finds in this village only women, children, and old people. The men go to hunt deer, the skins of which are less valued than those from the northern coun-

${ }^{50}$ Georges Henri Victor Collot, A Journey in North America (2 vols., Paris, 1826), II, 40. Collot seems to have been speaking of the village proper (trading houses, etc.) when he gave his population estimate.

${ }^{51}$ Faye, "The Arkansas Post of Louisiana: French Domination," 719.

52 The census is Padron del Puesto de Arkanzas, 1798, AGI, PC, leg. 2365. 
try, buffalo which they salt for their use, and some beaver which they still find at a little distance. On their return home, they pass their time in playing games, dancing, drinking, or doing nothing, similar in this as in other things to the savage peoples with whom they pass the greater part of their lives, and whose habits and customs they acquire. ${ }^{53}$

That Arkansas Post still gave shelter mainly to hunters and Indian traders is attested to by all the early nineteenth-century descriptions of the place..$^{54}$ Indeed, that seems well-established. What was not hitherto appreciated is that this was a state of affairs which Captain Balthazar De Villiers had set out deliberately to correct, but with only a very limited success. Though there were a number of respectable families there, the Arkansas was still far from being rid of what the good captain had termed "the embarrassment of the hunters' families." Still, while Arkansas Post could not yet provide toutes les douceurs de la vie, it was nevertheless no longer le réduit le plus désagréable de l'univers.

\footnotetext{
${ }^{63}$ Francois Marie Perrin du Lac, Voyage dans les Deux Louisianes . . . en I801, 1802, et $1803 \ldots$. (Paris, 1805), 360.

${ }^{54}$ See, e. g., View of the Spanish Colony of the Mississippi, 1802, by a Resident Observer on the Premises (New Orleans, 1802); An Account of Louisiana, 1803 (Boston, Old South Leaflets, no. 105, n. d.), 6, 11.
} 